\title{
Cerebral infarction caused by traumatic carotid artery dissection
}

\author{
Travmatik karotid arter diseksiyonuna bağlı serebral enfarktüs
}

\author{
Ayşegül BAYIR, ${ }^{1}$ Demet AYDOĞDU KIREŞI, ${ }^{2}$ Ali SÖYLEMEZ, ${ }^{3}$ Osman DEMİRCİ ${ }^{4}$
}

Traumatic carotid artery dissection, if not diagnosed and treated early, is a serious problem with permanent neurological deficit and a high mortality rate of up to $40 \%$. We present a case with delayed diagnosis of traumatic carotid artery dissection in a 21-year-old female. While there were no ischemic infarct findings on the admission cerebral computerized tomography $(\mathrm{CT})$, such findings were observed on two cerebral CTs taken because of the left hemiplegia noticed seven days later when the patient regained consciousness. The patient was referred to our emergency service, and definitive diagnosis was achieved with arterial Doppler ultrasonography, cerebral magnetic resonance imaging (MRI), diffusion MRI, and MR angiography. We did not consider invasive treatment since the neurological damage was permanent and dissection grade was IV according to angiography findings. The case was discharged within a week and physiotherapy was advised. Despite the advances in diagnostic methods, diagnosis of traumatic carotid artery dissection is still missed or delayed, as in the case presented here. Early diagnosis can ameliorate permanent neurological damage or even prevent it. However, the vital factors for early diagnosis are the obtained anamnesis leading to appropriate radiological examinations, detailed physical examination and high clinical suspicion.

Key Words: Doppler ultrasonography; internal carotid artery; magnetic resonance angiography; traumatic dissection.
Travmatik karotid arter diseksiyonu eğer erken tanı konulup tedavi edilmezse kalıcı nörolojik defisit ve \%40'lara varan ölüm oranı yaratabilen ciddi bir sorundur. Bu yazıda, travmatik karotid arter diseksiyonu tanısı geç dönemde konan 21 yaşında kadın hasta sunuldu. Kabulde çekilen beyin bilgisayarlı tomografisinde (BT) iskemik enfarkt bulgular yok iken, bilinci açıldıktan sonra yedinci gün sol hemiplejisi fark edildiğinde çekilen ikinci beyin BT'sinde enfarktüs bulguları saptandı. Hasta acil servise kabul edildi. Kesin tan1, arteriyel Doppler ultrasonografi, serebral manyetik rezonans görüntüleme (MRG), difüzyon $M R G$ ve $M R$ anjiyografi ile konuldu. Hastada kalıcı nörolojik hasar geliştiği ve anjiyografi bulgularına göre evre IV olduğu için invaziv tedavi düşünülmedi. Hasta fizyoterapi tavsiye edilerek bir hafta içinde taburcu edildi. Tanısal yöntemlerdeki gelişmelere rağmen travmatik karotid arter diseksiyonunun tanısı bu olguda olduğu gibi halen atlanmakta veya gecikmektedir. Erken tanı kalıcı nörolojik hasarı önleyebilir ya da hafifletebilir. Bununla birlikte erken tanı için en önemli faktörler uygun radyolojik incelemeyi yönlendirecek anamnez, ayrıntılı fiziksel inceleme ve yüksek klinik şüphedir.

Anahtar Sözcükler: Doppler ultrasonografi; internal karotid arter; manyetik rezonans anjiyografi; travmatik diseksiyon.
The incidence of internal carotid artery dissection (ICAD) caused by blunt trauma is unknown, since the onset of symptoms and signs are frequently delayed, ${ }^{[1]}$ but it has been reported to be $0.08 \%{ }^{[2]}$ Traumatic ICAD is often accompanied by thrombosis, resulting in permanent neurological deficits and carrying a mortality rate of up to $40 \%{ }^{[3,4]}$ In this case report, we present a patient whose ICAD was diagnosed one week after being involved in a motorcycle accident and hospitalized at an outlying hospital.
${ }^{1}$ Department of Emergency Medicine, Selcuk University Selcuklu Faculty of Medicine, Konya; ${ }^{2}$ Department of Radiology, Selcuk University Meram Faculty of Medicine, Konya; ${ }^{3}$ Department of Neurology, Suleyman Demirel University Faculty of Medicine, Isparta; ${ }^{4}$ Department of Emergency Medicine, Siirt State Hospital, Siirt, Turkey.
${ }^{1}$ Selçuk Üniversitesi Selçuklu Tıp Fakültesi, Acil Tıp Anabilim Dal Konya; ${ }^{2}$ Selçuk Üniversitesi Meram Tıp Fakültesi, Radyoloji Anabilim Dalı, Konya; ${ }^{3}$ Süleyman Demirel Üniversitesi Tıp Fakültesi, Nöroloji Anabilim Dalı, Isparta; ${ }^{4}$ Siirt Devlet Hastanesi Acil Servisi, Siirt. 


\section{CASE REPORT}

A 21-year-old female motorcycle passenger was involved in a motor vehicle accident and was brought to the emergency service of a rural government hospital. She was comatose on presentation, and was found to have left radius-ulna fractures on plain films and cerebral edema on non-contrast head computerized tomography (CT) scan. In the neurosurgical intensive care unit (ICU), as she regained consciousness over the next few days, weakness of her left arm and leg was noted. A repeat head CT showed a hypodense infarct in the right frontoparietal and basal ganglion areas (Fig. 1a). With a diagnosis of 'acute embolic stroke', she was transferred to our tertiary care university hospital emergency department.

Upon arrival, she was conscious and cooperative with complaints of left hemiparesis. Her vital signs were blood pressure (BP) 120/70 $\mathrm{mmHg}$, pulse rate $72 /$ min, respiratory rate $18 / \mathrm{min}$ and temperature $36.8^{\circ} \mathrm{C}$. Her pupillary exam was normal and her Glasgow Coma Score was 13. Motor strength was $1 / 5$ in the left upper extremity and $1 / 5$ in the lower extremity. Her left Babinski reflex was positive. Given her clinical picture of posttraumatic stroke, carotid artery injury was suspected.

Diffusion magnetic resonance imaging (MRI) of the brain demonstrated decreased diffusion in the ADC map area, compatible with a large acute infarct and mainly diffusion in the frontal-temporal and parietal zone of the right cerebral hemisphere (Fig. 1b). On T2 axial MR images, loss of flow in the right ICA was observed at the level of the cavernous sinus on the right. Signal alterations consistent with acute infarct were seen in the right frontal, temporal and parietal lobes, including the basal ganglia. The right carotid superior was filled to the Circle of Willis, and subacute hematoma and right ICAD at the level of the inferior pars petrosa were seen (Figs. 1c, d). On MR angiography, no flow of contrast was seen in the right ICA and carotid bulbus superior, or in the middle portion of the right ICA (Figs. 1e, f). Carotid Doppler ultrasonography showed dissection of the right ICA and a thrombus causing total occlusion beginning at the bifurcation (Figs. 1g, h).

The patient was hospitalized for treatment and follow-up. Since permanent neurological damage had developed and the infarct area was large, anticoagulation was not performed due to concerns that such treatment might trigger hemorrhage in the ischemic infarct area. The patient was discharged with follow-up in the neurology and physical medicine and rehabilitation clinics. The patient's neurological symptoms and signs (permanent left hemiplegia) were unchanged during three months of follow-up.

\section{DISCUSSION}

Traumatic ICAD is a rare and serious cause of embolic stroke in the younger age group. The basic pathophysiological mechanism is stretching of the artery through rotation-hyperextension or distractionflexion. ${ }^{[5]}$ While only $10 \%$ of cases have an immediate onset of symptoms, in most patients, clinical signs of the dissection occur within the first 24 hours following the traumatic event. No symptoms occur within the first 24 hours after trauma in 35\% of cases. In patients with traumatic ICAD who exhibit neurologic deficits, brain CT performed within the first 24 hours is usually non-diagnostic. ${ }^{[6]}$

Traumatic ICAD is usually suspected and diagnosed when a neurological deficit develops unexpectedly after trauma, evolving clinically into a 'stroke' in $80 \%$ of the cases during the first week after symptom onset. ${ }^{[1]}$ In addition to a detailed history and careful physical examination, duplex carotid ultrasound, CT, CT angiography, MRI, MR angiography, and conventional angiography are imaging studies that can be performed to diagnose traumatic ICAD. ${ }^{[7,8]}$

The present case was referred to us with a diagnosis of acute embolic stroke although she had no signs of ischemia on her CT performed at the first hospital. A comprehensive neurologic exam could not be performed secondary to her depressed level of consciousness. In light of the patient's young age and history of trauma, we suspected traumatic ICAD when we viewed her $\mathrm{CT}$ and found corresponding neurologic deficits. To make the definitive diagnosis in our patient, we performed brain MRI, diffusion MRI, carotid Doppler ultrasound, and MR angiography.

Traumatic CAD is divided into five grades according to angiographic findings, and therapy is undertaken accordingly: Grade I: with $\leq 25 \%$ narrowing of the lumen, luminal disruption or dissection; Grade II: $>25 \%$ narrowing of the lumen, together with dissection or intramural hematoma, intraluminal thrombus or split flap, Grade III: pseudoaneurysm, Grade IV: complete occlusion, and Grade V: signs of transection with contrast extravasation. ${ }^{[9]}$ Grade I traumatic ICAD is treated conservatively with anticoagulants, as only $7 \%$ will progress to a higher grade. However, $70 \%$ of Grade II dissections rapidly progress to pseudoaneurysm formation and occlusion, and thus require aggressive surgical treatment. ${ }^{[5]}$

With the latest improvements in endovascular stenting, successful results have been obtained in Grade I and Grade II ICADs. ${ }^{[10]}$ Grade IV dissections are usually complicated by cerebral embolism and stroke. Recanalization procedures in Grade IV traumatic ICAD are associated with a high rate of complications, thus observation and/or anticoagulation is advised. Grade 
V ICAD requires urgent surgical ligation and hemorrhage control. ${ }^{[5]}$

Our patient had a Grade IV ICAD, as diagnosed by MR angiography. The delay in diagnosis at the outlying hospital may have led to the development of permanent neurologic deficits. MR angiography revealed that the dissected superior carotid artery was filled with Willis Polygon.

Traumatic ICAD is a rare occurrence and its diagnosis can easily be missed or delayed despite advances in imaging procedures. Obtaining a detailed history and performing a comprehensive examination
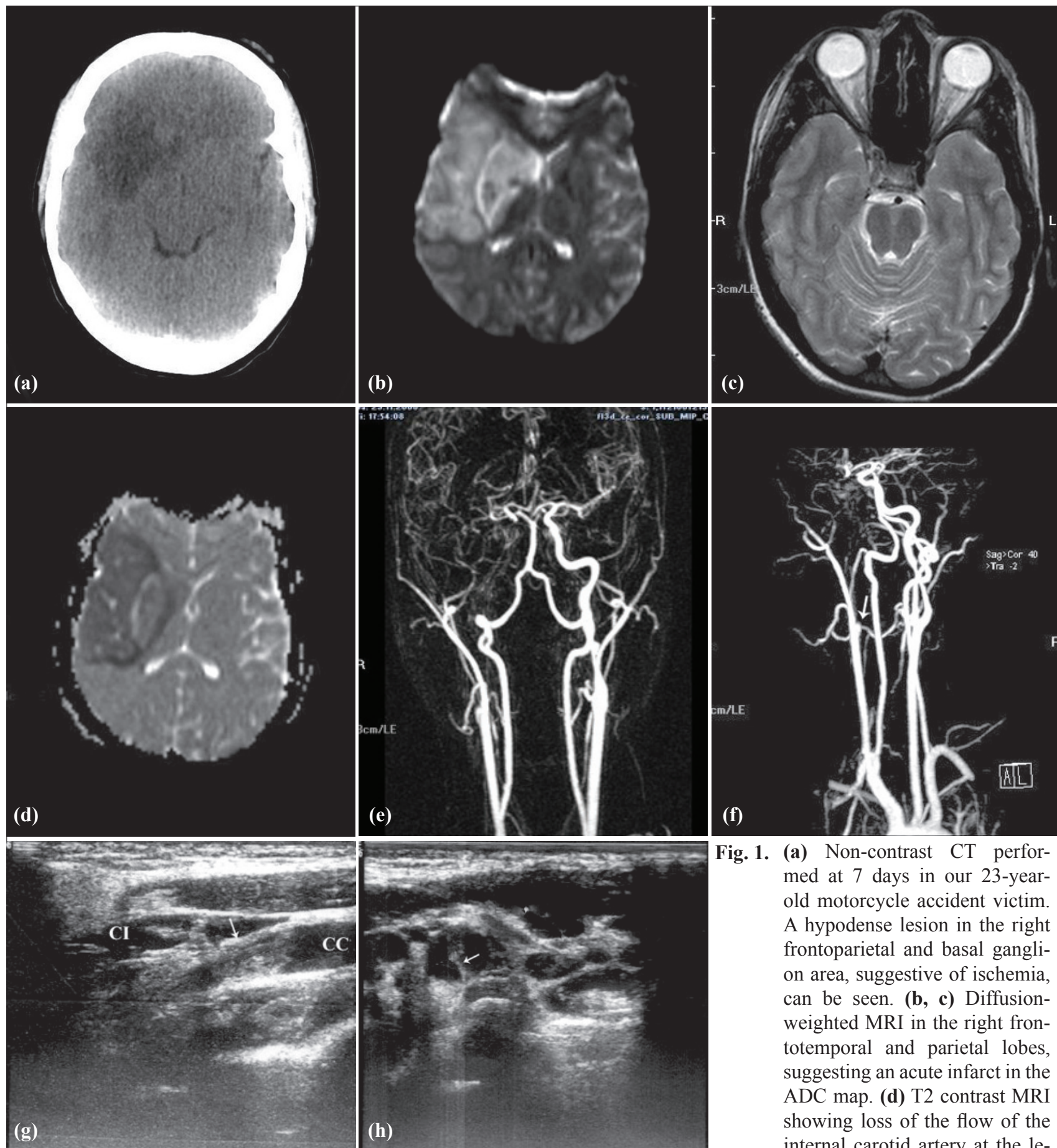

Fig. 1. (a) Non-contrast CT performed at 7 days in our 23-yearold motorcycle accident victim. A hypodense lesion in the right frontoparietal and basal ganglion area, suggestive of ischemia, can be seen. (b, c) Diffusionweighted MRI in the right frontotemporal and parietal lobes, suggesting an acute infarct in the ADC map. (d) T2 contrast MRI showing loss of the flow of the internal carotid artery at the level of the cavernous sinus on the right. (e, f) Contrast MR angiogram showing cut-off of flow in the internal carotid artery at the level of the carotid bulb. Flow is also absent in the right middle cerebral artery. Longitudinal (g) and transverse (h) Doppler ultrasound images of the right internal carotid artery just superior to the carotid bulb showing a linear echogenic band (white arrow) in the lumen, compatible with dissection. 
will lead the clinician to suspect ICAD in the setting of post-traumatic unilateral neurologic abnormalities with a normal or near-normal non-contrast CT. Carotid Doppler is an easily performed study that can rule out the presence of ICAD in suspicious cases. Advances in CT and MR angiography techniques and machines have made it possible to establish a rapid and accurate diagnosis. After an accurate diagnosis has been made, immediate treatment to reduce complications and optimize outcome should be performed.

\section{REFERENCES}

1. Blanco Pampín J, Morte Tamayo N, Hinojal Fonseca R, Payne-James JJ, Jerreat P. Delayed presentation of carotid dissection, cerebral ischemia, and infarction following blunt trauma: two cases. J Clin Forensic Med 2002;9:136-40.

2. Davis JW, Holbrook TL, Hoyt DB, Mackersie RC, Field TO Jr, Shackford SR. Blunt carotid artery dissection: incidence, associated injuries, screening, and treatment. J Trauma 1990;30:1514-7.
3. Hughes KM, Collier B, Greene KA, Kurek S. Traumatic carotid artery dissection: a significant incidental finding. Am Surg 2000;66:1023-7.

4. Martin RF, Eldrup JJ, Clark DE, Bredenberg CE. Blunt trauma to the carotid arteries. J Vasc Surg 1991;14:789-93.

5. Yang ST, Huang YC, Chuang CC, Hsu PW. Traumatic internal carotid artery dissection. J Clin Neurosci 2006;13:123-8.

6. Sasser PL, Stein MA, Johnson JK. Blunt carotid artery trauma: diagnosis and management. Contemp Surg 1992;41:559.

7. Liu AY, Paulsen RD, Marcellus ML, Steinberg GK, Marks MP. Long-term outcomes after carotid stent placement treatment of carotid artery dissection. Neurosurgery 1999;45:1368-74.

8. Zetterling M, Carlström C, Konrad P. Internal carotid artery dissection. Acta Neurol Scand 2000;101:1-7.

9. Biffl WL, Moore EE, Offner PJ, Brega KE, Franciose RJ, Burch JM. Blunt carotid arterial injuries: implications of a new grading scale. J Trauma 1999;47:845-53.

10. Pagnotta P, Briguori C, Saluzzo CM, Presbitero P. Endovascular treatment of traumatic bilateral internal carotid artery dissection. J Invasive Cardiol 2009;21:E6-8. 